\title{
The Association of a Longidorus Species with Stunting and Root Damage of Loblolly Pine (Pinus taeda L.) Seedlings
}

\author{
Stephen W. Fraedrich and Michelle M. Cram, USDA Forest Service, 320 Green St., Athens, GA 30602
}

\begin{abstract}
Fraedrich, S. W., and Cram, M. M. 2002. The association of a Longidorus species with stunting and root damage of loblolly pine (Pinus taeda L.) seedlings. Plant Dis. 86:803-807.

A Longidorus species was consistently associated with patches of stunted and chlorotic loblolly pine seedlings at a forest-tree nursery in Georgia. Seedlings from affected areas had poorly developed root systems that lacked lateral and feeder roots. Longidorus population densities in composite soil samples from the margins of patches ranged from 9 to 67 nematodes per $100 \mathrm{~cm}^{3}$ of soil. In a growth chamber experiment, seedling root dry weight decreased with respect to the initial Longidorus dose as well as the final Longidorus populations in containers. The dry root weight of seedlings were $0.117,0.090,0.066$, and $0.065 \mathrm{~g}$ in containers initially infested with 0 , 50, 100, and 200 Longidorus, respectively. Lateral and fine roots were lacking on seedlings at the highest doses. Populations of Longidorus increased in all containers during the experiment. Damage to loblolly pine seedlings caused by Longidorus is a previously undescribed problem in southern pine nurseries. Proper diagnosis of the problem by nematode testing laboratories may require the use of extraction techniques specific for larger nematodes such as Longidorus.
\end{abstract}

Many species of plant parasitic nematodes are associated with roots of conifers (10), and some can cause significant damage $(9,11,12,16)$. Nursery seedlings are particularly vulnerable to damage by nematodes because of the continuous culture of single species, use of irrigation to maintain soil moisture, and maintenance of high soil fertility for optimal plant growth (12). Fumigation has been used routinely for more than 40 years in many southern forest-tree nurseries to control weeds, insects, fungal pathogens, and nematodes. However, the most widely used fumigant, methyl bromide (6), is scheduled to be phased out by 2005. Many aspects of nursery operations have changed since the 1950 s, and there is presently a lack of information about soilborne diseases that may affect pine production in southern nurseries.

Areas of stunted pine seedlings have been periodically observed in fields at the Flint River Nursery (Byromville, GA) since its establishment in 1987. During 1998 and 1999, patches of stunted and chlorotic loblolly pine (Pinus taeda L.) seedlings occurred in one field at this nursery. Soil samples from the affected areas were forwarded to a nematode testing laboratory for evaluation of plant parasitic

Corresponding author: Stephen Fraedrich E-mail: sfraedrich@fs.fed.us

Accepted for publication 4 April 2002.

Publication no. D-2002-0521-02R

This article is in the public domain and not copyrightable. It may be freely reprinted with customary crediting of the source. The American Phytopathological Society, 2002. nematodes, and seedlings were sampled for fungal pathogens, but a definitive cause of the problem could not be determined. Sections of the field affected by the disease were fumigated in the spring of 2000, and the disease was not observed in the pine seedling crop produced in these sections during 2000.

In July 2000, we again observed patches of stunted loblolly pine seedlings but in different sections of the field. These sections contained a fumigation study (3) that was in its third year of continuous pine seedling production. Seedling damage was observed in nonfumigated control plots, and soil in these plots had not been fumigated since October 1993. Many seedlings were chlorotic and severely stunted in affected areas (Fig. 1A). Compared to healthy seedlings, stunted seedlings had poorly developed root systems that lacked lateral, feeder, and mycorrhizal roots (Figs. $1 \mathrm{~B}$ and $1 \mathrm{C})$. Soil samples were forwarded to a nematode-testing laboratory where lesion (Pratylenchus sp.) and ring (Criconemella sp.) nematodes were found at low levels in areas with diseased seedlings as well as areas with healthy seedlings. Roots were plated on various agar media, and Fusarium spp. were routinely isolated from both healthy and diseased seedlings. A Rhizoctonia-like fungus was also occasionally isolated from roots of stunted seedlings in some patches. Upon closer inspection of the unwashed roots in water under a dissecting microscope, we routinely observed needle nematodes (Longidorus sp.) associated with diseased seedlings. This nematode had not been reported by the nematode testing laboratory. We summarize in this paper our findings of a survey for a Longidorus sp. in affected areas of seedbeds at the Flint River Nursery and results of a growth chamber experiment to determine the effect of Longidorus sp. on loblolly pine seedlings.

\section{MATERIALS AND METHODS}

Field survey. Seedlings and soil were sampled in four areas that contained patches of stunted loblolly pine seedlings. Each patch occurred in a separate bed within a 12-seedbed area of one field. Patches ranged from 3 to $9 \mathrm{~m}$ long and were one seedbed $(1.2 \mathrm{~m})$ wide. Samples of seedlings with soil attached were collected from each of the four patches in August and October 2000. In August, diseased seedlings were collected at patch centers and margins, and healthy-appearing seedlings were collected at distances of 1.5 and $3.0 \mathrm{~m}$ outside the margins of patches (seven sample locations per patch). In October, seedlings were collected at patch margins and at distances of $1.5 \mathrm{~m}$ outside the patch margins (four sample locations per patch). At each sample location and sample time, 10 to 25 seedlings were lifted. Seedlings with attached soil were placed in plastic bags. A $25 \mathrm{~g}$ sample of soil from the root zone of seedlings at each sample location was used for nematode extractions. At patch centers, only 8 to $15 \mathrm{~g}$ of soil was used because of the sparseness of seedling roots and lack of associated soil. The population density of Longidorus in these samples was expressed on a $25 \mathrm{~g}$ weight basis. Nematodes were extracted using the technique of Flegg (5) but the technique was modified such that $90 \mu \mathrm{m}$ aperture sieves were used in place of 150 $\mu \mathrm{m}$ sieves. In addition, nematodes and debris from sieves were placed in water under a dissecting scope, and nematodes were counted directly without the use of the Baermann funnel apparatus.

Composite soil samples were collected with a soil sampler in September and again in October 2000 from the centers, margins, and $1.5 \mathrm{~m}$ outside the margins of each of the four patches (five sample locations per patch). Soil samples from each location consisted of 5 to 6 soil cores $(2.5 \mathrm{~cm}$ diameter to a $15 \mathrm{~cm}$ depth). Nematodes were extracted from $200 \mathrm{~cm}^{3}$ of soil using the technique of Flegg (5) with $90 \mu \mathrm{m}$ aperture sieves as previously noted. In addition, Kimwipes (Kimberly-Clark Corp., Roswell, GA) were used instead of $90 \mu \mathrm{m}$ aperture nylon screen in the Baermann funnel apparatus. After $48 \mathrm{~h}$, about $25 \mathrm{ml}$ of water with nematodes was removed from the Baermann funnels, and Longi- 
dorus were counted under a dissecting microscope. Debris with nematodes was washed from the Kimwipes into a petri dish, and remaining Longidorus were counted under a dissecting microscope by systematically sorting through the debris.

Growth chamber experiment. The objective of the experiment was to examine
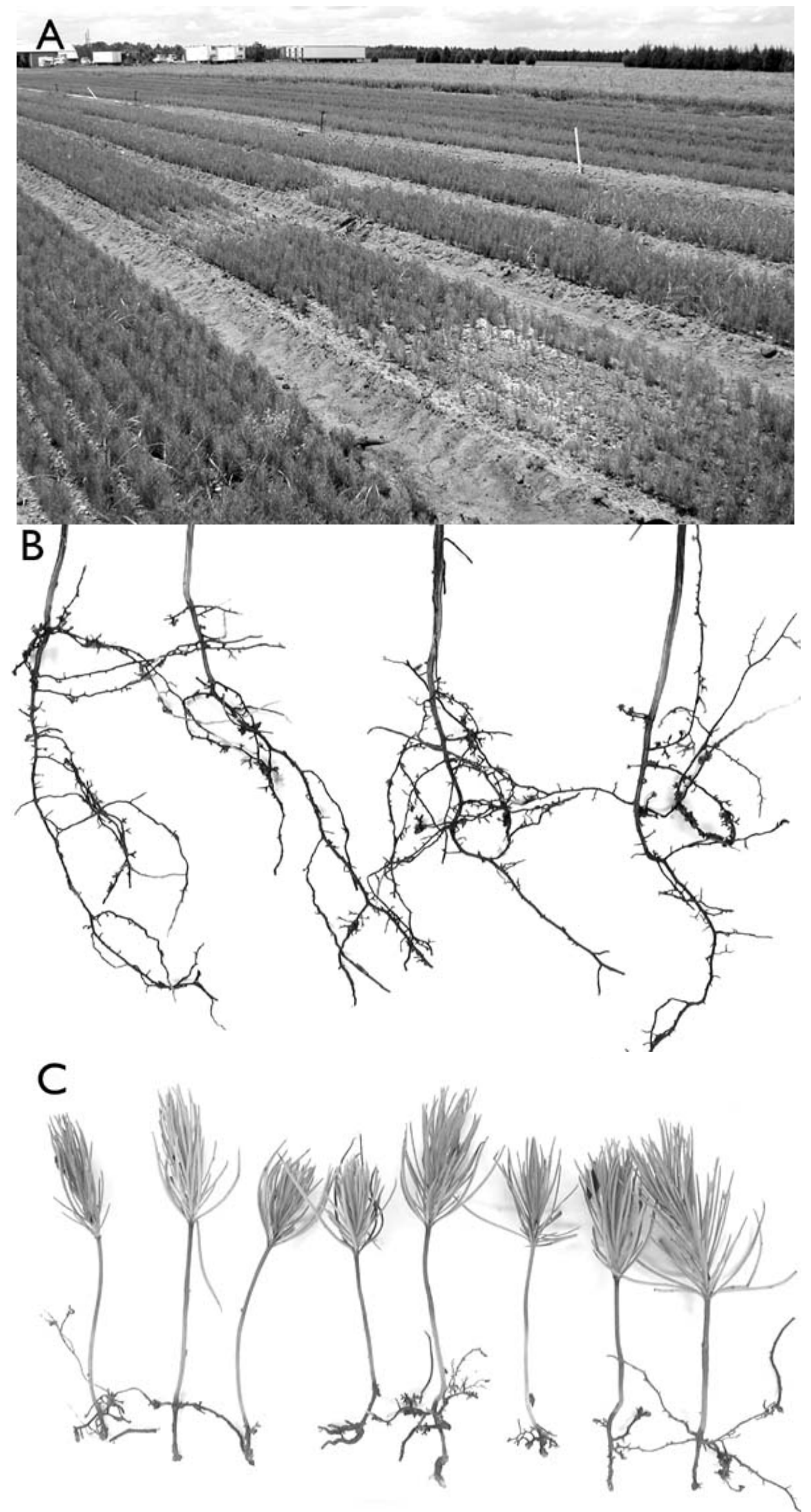

Fig. 1. A, patch of stunted loblolly pine seedlings at Georgia nursery. Root systems of healthy $\mathbf{B}$, and diseased $\mathbf{C}, 10$-week old seedlings.

the effect of the Longidorus sp. on growth of loblolly pine seedlings. Longidorus were extracted from soil using the technique of Flegg (5) with the $90 \mu \mathrm{m}$ aperture sieves and without additional modifications. The nematodes were hand picked, placed in water in groups of 50 , and stored at $5^{\circ} \mathrm{C}$ for up to 48 $\mathrm{h}$ before introduction into containers. Soil was obtained from areas of the nursery not affected by disease and was microwaved in $2 \mathrm{~kg}$ batches for $8 \mathrm{~min}$. Approximately $330 \mathrm{~g}$ of soil was placed in each container $(7 \mathrm{~cm}$ high by $10 \mathrm{~cm}$ wide). Loblolly pine seeds were surfaced sterilized with hydrogen peroxide $(30 \%)$ for $60 \mathrm{~min}$ (1), rinsed with sterile distilled water, and stratified for 30 to 60 days. Seeds were germinated under sterile conditions, and five germinated seeds were transplanted to containers with microwaved soil.

Needle nematodes were added to containers at rates of $0,50,100$, or 200 individuals per container, and there were four replications of each nematode dose. The seedlings were placed in a growth chamber at $22^{\circ} \mathrm{C}$ with a 14 -h photoperiod and were watered every 1 to 3 days as needed. At the end of 22 weeks, seedlings were removed from containers and dried at $80^{\circ} \mathrm{C}$ for $48 \mathrm{~h}$. The dry root and shoot weights of each seedling was determined. The final population of Longidorus in containers was determined using the extraction technique of Flegg (5) with the $90 \mu \mathrm{m}$ aperture sieve and without additional modification.

The experiment was established as a completely randomized design with four treatments (Longidorus doses) and four replications (containers) per treatment. The effect of the initial Longidorus dose and final Longidorus populations on seedling root and shoot dry weights was determined by regression analysis (4). A nonlinear, negative exponential model was used to characterize the relationship between the initial Longidorus dose and seedling root dry weight. Parameter estimates were determined using PROC NLIN (The SAS System for Windows, Version 8.01, SAS Institute, Inc., Cary, NC). The criteria for fit of the model were based on the mean square error (MSE), the significance of the overall regression, and a lack of fit analysis. Linear regression using PROC REG (The SAS System for Windows, Version 8.01) was used to analyze the relationship between initial Longidorus dose and seedling shoot dry weight, and relationships between final population of Longidorus per container and seedling root and shoot dry weights. Longidorus populations in containers at the end of the experiment were analyzed among treatments using an analysis of variance and Tukey's honest significant difference (HSD) procedure $(\alpha=$ 0.05 ) for mean separation (8).

\section{RESULTS}

Longidorus survey. In August 2000, Longidorus population densities were 
greater in soil samples from the root zone of seedlings at the centers and margins of patches than areas with healthy seedlings at distances of 1.5 and $3.0 \mathrm{~m}$ from the patch margins (Fig. 2A). The October sampling of soil from the root zone provided similar results. An average of 25.8 Longidorus per $25 \mathrm{~g}$ soil (range: 10 to 52 ) were extracted at the margins of affected areas and an average of 1.5 Longidorus (range: 0 to 6 ) were extracted $1.5 \mathrm{~m}$ outside the margins.

In the composite soil samples obtained in September, Longidorus were most frequently extracted at the margins of affected areas (Fig. 2B). Fewer nematodes were extracted at the centers of affected areas or $1.5 \mathrm{~m}$ outside the margins of the affected areas. The findings were similar for the composite soil samples collected in October. The mean number of Longidorus extracted at the margins of patches was $17.5 / 100 \mathrm{~cm}^{3}$ soil (range: 9 to 30 ), and at $1.5 \mathrm{~m}$ outside the margins only $2.5 / 100$ $\mathrm{cm}^{3}$ (range: 1 to 7 ).

Growth chamber experiment. Damage to root systems similar to that found in seedbeds occurred in containers infested with the Longidorus sp. Seedlings typically lacked lateral and feeder roots in containers infested with 100 and 200 individuals. Seedling root dry weight decreased exponentially as the initial Longidorus dose increased (Fig. 3A, $\mathrm{MSE}=0.00026, P=0.0006)$, and there was no evidence of lack of fit for the relationship $(P=0.369)$. Root dry weight was also inversely related to the final number of Longidorus per container (Fig. $\left.3 \mathrm{~B}, R^{2}=0.60, P=0.0004\right)$. Shoot dry weight did not vary with respect to initial dosage levels of Longidorus $\left(R^{2}=0.078\right.$, $P=.296)$ or final counts of Longidorus $\left(R^{2}=0.0005, P=0.933\right)$ in containers. Mean shoot dry weight ranged from 0.14 to $0.17 \mathrm{~g}$ among treatments.
Longidorus increased in all containers during the experiment, but final populations differed among treatments $(P=0.01)$. Containers initially infested with 50, 100, or 200 Longidorus had a average of 555, 582, and 672 Longidorus, respectively, at the end of the experiment, and there were no differences among these treatments. Containers initially free of nematodes at the beginning of the experiment had been contaminated and had an average of 74 Longidorus per container at the end of the experiment. Nonetheless, control containers had significantly fewer Longidorus than containers of the other treatments.

\section{DISCUSSION}

Longidorus spp. have been reported to damage pine seedlings in Germany (15), and have been previously found in soil from areas where southern pines were grown $(7,13)$. In a survey of soils of southern nurseries, Hopper (7) found the needle nematode at only 1 of 16 nurseries. However, we have not found published accounts of Longidorus spp. parasitizing and damaging roots of loblolly pine or other southern pine species. Based on the results of our survey and growth chamber experiment, we believe that the Longidorus sp. is responsible for the damage that we observed on loblolly pine seedlings at the Flint River Nursery. The possible involvement of fungal pathogens in the seedling losses at this nursery requires additional study.

The threat of this Longidorus sp. to pine seedling production is presently not known. During 2000, the disease was primarily restricted to areas of 12 seedbeds that had not been fumigated in recent years and approximately $4 \%$ of the nonfumigated area was affected. However, during the summer of 2001, the problem recurred in areas of the field fumigated in 2000. Thus far, the problem has been localized to sec- tions of this one field and has not spread to other fields. In fact, six consecutive crops of pine seedlings were produced in nonfumigated study plots in an adjacent field between 1995 and 2000, and the disease did not develop.

Specimens of the Longidorus sp. were forwarded to the USDA, ARS, Nematology Laboratory in Beltsville, MD for identification. The nematode is not believed to conform to any known Longidorus sp. and is presently regarded as undescribed ( $\mathrm{Z}$. Handoo, personal communication). The nematode is extremely large (7 to $8 \mathrm{~mm}$ long), and is found at low population levels compared to many nematodes that damage plants. These factors may partially account for the failure to detect Longidorus by nematode testing laboratories that processed soil from affected areas. The techniques for extraction of large nematodes such as Longidorus spp. are quite specific $(5,14)$, and methods routinely used for the extraction of plant parasitic nematodes from soil may not be suitable for extraction of larger nematodes. In our laboratory, we initially substituted Kimwipes for the 90 $\mu \mathrm{m}$ aperture nylon screen used by Flegg (5) in the Baermann funnel apparatus. Kimwipes were not a suitable support for extraction of this Longidorus $s p$. because $70 \%$ of the Longidorus in samples did not move through this material. In a small experiment that we conducted, three times as many Longidorus could be obtained from soil samples using a $90 \mu \mathrm{m}$ aperture nylon screen in the Baermann funnel apparatus compared to Kimwipes (unpublished data).

In patch centers, fewer nematodes were extracted in the composite soil samples (range: 2 to 8 nematodes per $100 \mathrm{~cm}^{3}$ ) than from soil obtained from the root zone of seedlings (range: 7 to 48 nematodes per 25 g). The difference is most likely due to the very limited root distribution of seedlings

\begin{tabular}{|c|c|c|c|c|c|c|}
\hline A. $\begin{array}{c}0.2 \\
(0-1)\end{array}$ & $\begin{array}{r}0.5 \\
(0-8)\end{array}$ & $\begin{array}{r}11.7 \\
(8-17)\end{array}$ & $\begin{array}{c}26.6 \\
(7-48)\end{array}$ & $\begin{array}{c}14.4 \\
(4-26)\end{array}$ & $\begin{array}{c}0.5 \\
(0-2)\end{array}$ & $\begin{array}{c}0.2 \\
(0-1)\end{array}$ \\
\hline$+3.0 \mathrm{~m}$ & $+1.5 \mathrm{~m}$ & $M$ & $(\mathrm{C})$ & $M$ & $+1.5 \mathrm{~m}$ & $+3.0 \mathrm{~m}$ \\
\hline \multicolumn{2}{|c|}{$\begin{array}{l}\text { Healthy-appearing } \\
\text { seedlings }\end{array}$} & \multicolumn{2}{|r|}{ Stunted seedlings } & & \multicolumn{2}{|c|}{$\begin{array}{l}\text { Healthy-appearing } \\
\text { seedlings }\end{array}$} \\
\hline
\end{tabular}

\begin{tabular}{|c|c|c|c|c|c|}
\hline \multirow[t]{2}{*}{ B. } & $\begin{array}{c}4.5 \\
(0-12)\end{array}$ & $\begin{array}{r}25.4 \\
(9-67)\end{array}$ & $\begin{array}{c}4 \\
(2-8)\end{array}$ & $\begin{array}{c}21.3 \\
(12-26)\end{array}$ & $\begin{array}{c}1 \\
(0-2)\end{array}$ \\
\hline & $+1.5 \mathrm{~m}$ & $M$ & 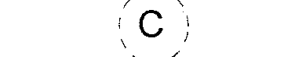 & $M$ & $+1.5 m$ \\
\hline & aring & & Stunted seedlings & & $\begin{array}{l}\text { Healthy-appearing } \\
\text { seedlings }\end{array}$ \\
\hline
\end{tabular}

Fig. 2. Mean number (and range) of Longidorus per $25 \mathrm{~g}$ soil collected from the root zone of loblolly pine seedlings $\mathbf{A}$, and mean number (and range) of Longidorus per $100 \mathrm{~cm}^{3}$ soil extracted from composite soil samples B. Mean values are from four areas with patches of stunted seedlings, and includes sample locations at the centers $(\mathbf{C})$, margins $(\mathbf{M})$, and $1.5 \mathrm{~m}$ (and $3.0 \mathrm{~m}[\mathbf{A}])$ from the margins of patches. 
in the patch centers and the close association of Longidorus with the pine roots. The composite soil samples probably included many cores void of roots, which greatly reduced the presence of Longidorus in these soil samples.

The presence of Longidorus in control containers at the end of the growth chamber experiment was most likely due to contamination from infested containers. Containers were randomized in the growth chamber in close proximity to one another. The contamination of noninfested containers probably resulted from splash during watering. Although reductions in the size of root systems were found in our growth chamber experiments, we did not observe the stunting of seedling shoots that was prevalent under field conditions in affected areas. However, stresses due to high summer temperatures and daily water deficits that would occur normally under field conditions were not imposed in the growth chamber experiments.

Considerable changes have occurred in many aspects of forest-tree nursery operations since nursery managers began fumigating more than 40 years ago. From a pest management standpoint, one important change is the placement of newer nurseries
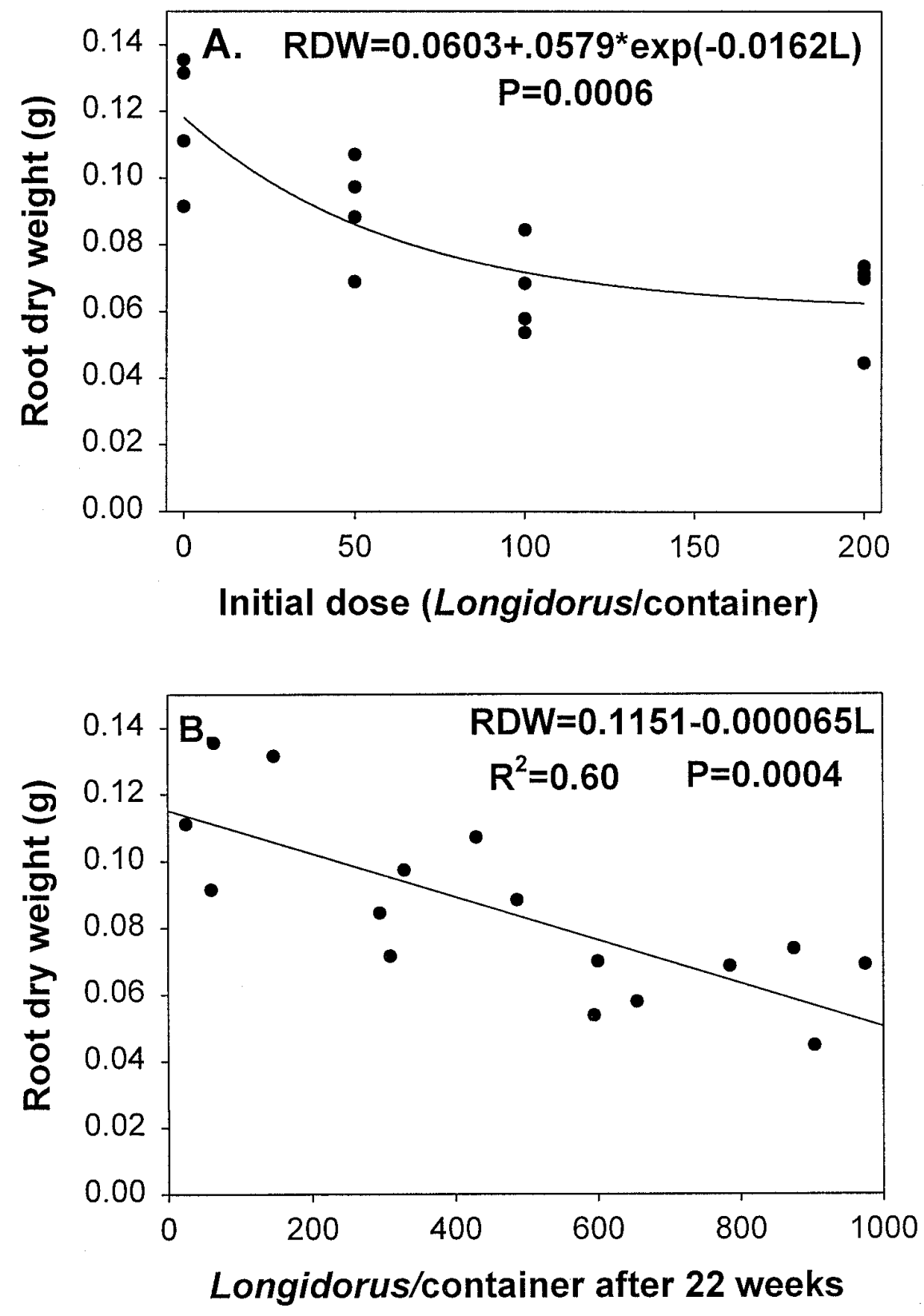

Fig. 3. Relationships between the initial dose of Longidorus (L) and root dry weight (RDW) of loblolly pine seedlings A, and final population of Longidorus per container and root dry weight $\mathbf{B}$. Data was collected 22 weeks after infestation. Each data point represents the mean root dry weight of five seedlings per container. on sites with sandier soils than in the past (2). The soil type at the Flint River Nursery is a loamy sand, and classified in the Eustis soil series. Although sandier soils provide better drainage that may prevent the development of some root diseases, Longidorus spp. are usually confined to sandy and sandy loam soils (14).

Damage to pine seedlings by the needle nematode is a previously undescribed problem in southern nurseries. Nursery managers and pest management specialists who suspect nematode damage to pine crops should alert nematode testing laboratories to examine soil samples for Longidorus spp. Where patches of stunted seedlings occur, soil samples should be taken at the margins of the patches, and stunted seedlings with rhizosphere soil should be lifted for evaluation. Nematode testing laboratories should consider using the procedure of Flegg (5) or other techniques (14) specific for extraction of larger nematodes such as Longidorus spp. when nematode damage is suspected on seedlings of loblolly pine or other southern pines.

\section{ACKNOWLEDGMENTS}

We thank Zafar Handoo for his taxonomic evaluation of the Longidorus sp. and manuscript review; Jack Sutherland for helpful information and advice regarding nematode biology and sampling and manuscript review; Stan Zarnoch for statistical advice and manuscript review; Kerry Britton, Thomas Harrington, and two anonymous reviewers for their helpful comments and suggestions on the manuscript; Susan Best for technical assistance; and personnel at the Flint River Nursery for their help and cooperation.

\section{LITERATURE CITED}

1. Barnett, J. P. 1976. Sterilizing southern pine seeds with hydrogen peroxide. Tree Planters' Notes 27:17-24.

2. Boyer, J. N. and South, D. B. 1984. Forest nursery practices in the South. South. J. Appl. For. 8:67-75.

3. Cram, M. M., Enebak, S., Dwinell, L. D. and Fraedrich, S. W. Effect of fumigation with chloropicrin and pre-plant application of EPTAM, individually and in combination, on the management of pests and production of seedlings in southern forest tree nurseries. Natl. Proc.: For. Conserv. Nursery Assoc. USDA For. Serv., Gen. Tech. Rep. In press.

4. Draper, N. R. and H. Smith. 1984. Applied Regression Analysis. 2nd ed. John Wiley and Sons. New York.

5. Flegg, J. J. M. 1967. Extraction of Xiphinema and Longidorus species from soil by a modification of Cobb's decanting and sieving technique. Ann. Appl. Biol. 60:429-437.

6. Fraedrich, S. W. and Smith, R. S. Jr. 1994. Soil fumigation in southern forest tree nurseries: Current status and future needs for pest management. Pages 267-282 in: Proc. of the second meeting of the IUFRO working party S2.07.09 (Diseases and insects in forest nurseries). R. Perrin, J. R. Sutherland, eds. Les Colloques, n 68. INRA. Paris, France.

7. Hopper, B. E. 1958. Plant-parasitic nematodes in soils of southern forest nurseries. Plant Dis. Rep. 42:308-314.

8. Milliken, G. A. and D. E. Johnson. 1984. Analysis of Messy Data. Vol. 1: Designed Experiments. Van Nostrand Reinhold, New York. 
9. Ruehle, J. L. 1964. Plant parasitic nematodes and their significance in forest nursery production. Pages 92-98 in: Proc. Region 8 For. Nurserymen's Conf. USDA For. Serv., Atlanta.

10. Ruehle, J. L. 1967. Distribution of plant parasitic nematodes associated with forest trees of the world. USDA For. Serv., Southeast. For. Exp. Stn. Asheville, NC.

11. Ruehle, J. L. 1969. Influence of stubby-root nematode on growth of southern pine seed- lings. For. Sci. 15:130-134

12. Ruehle, J. L. 1973. Nematodes and forest trees - types of damage to tree roots. Annu. Rev. Phytopathol. 11:99-118.

13. Ruehle, J. L. and J. N. Sasser. 1962. The role of plant-parasitic nematodes in stunting of pines in southern plantations. Phytopathology 52:56-68.

14. Shurtleff, M. C. and Averre, C. W. III. 2000. Diagnosing Plant Diseases Caused by Nematodes. American Phytopathological Society.
St. Paul, MN.

15. Sturhan, D. 1963. Der pflanzenparasitische nematode Longidorus maximus, seine biologie and okologie, mit untersuchungen an $L$. elongatus and Xiphinema diversicaaudatum. Z. Angew. Zool. 50:129-193.

16. Sutherland, J. R. 1977. Corky root disease of Douglas-fir seedlings: pathogenicity of the nematode Xiphinema bakeri alone and in combination with the fungus Cylindrocarpon destructans. Can. J. For. Res. 7:41-46. 